\title{
BOOK NOTICES
}

Tropical Ophthalmology. By R. H. ElLiOT, Lieut.rCol. I.M.S. (retired). Pp. xxiii and 525, with 7 plates and 117 illustrations. Oxford Medical Publications: Henry Frowde; Hodder and Stoughton, 1920. Price, 3is. 6d. net.

This book will be a boon to workers in all warm climates. Nothing of the kind has existed hitherto. And Col. Elliot, apart from his striking literary gifts, is one of the few men who have been in a position to write such a book. Given exceptional experience, the material must be collected, recorded and sifted steadily for many years. The holding of a teaching appointment is almost necessary as an incentive. And the widely scattered literature of the subject has to be sought, mostly buried under labels in no way suggestive of climatic influence.

As the author remarks, those qualified for this work are generally too climate-wearied to care for the task. Students in India have long felt the need for a readily available account of common tropical eye conditions.

The introductory chapters supply the keynote of the whole; they show an overpowering sense of the medical man's responsibilities and opportunities among the benighted poor in the East. The successful surgeon's life there is a hard one, upon which no man should venture unprepared, "to spend himself and be spent" while health and strength permit.

These early pages, with their insight and sympathy, show a much more intimate acquaintance with native life than is usual in Europeans in India. The first-hand narrative of appalling primitive ignorance and superstition possesses a vivid human interest.

Excellent descriptions are given of glare asthenopia and of sun blindness. Severer grades of the former seem to be relatively more common in Madras than further north in India, possibly owing to the want of the annual tonic influence of a well-marked cold season. A painfully true picture is drawn of the miserable condition of the child sufferers from (primary, epithelial) xerosis of the conjunctiva. Mention might be made of the abnormal pigmentation of the affected areas in Indians, including the whole of the corneal surface when this is involved. There is no such pigmentation in (secondary, parenchymatous) xerosis the result of cicatricial shrinking or exposure of the conjunctiva.

There is a sound practical chapter on the spread of ophthalmia in the East.

The comprehensive sections on injuries and diseases produced by 
animal pests and parasites are evidently the result of wide literary research, especially valuable to men scattered far afield.

The study of cataract couching and its results is one which Col. Elliot has made particularly his own, with characteristic thoroughness, as seen in his Hunterian Lectures for 1917.

No fault can be found with the very practical general directions for cataract extraction in the East. Without being hyper-critical, one might perhaps expect to hear more of Smith's intracapsular operation as a peculiarly Indian procedure, and to that extent tropical. Its extraordinary vogue in India is a matter of considerable interest, with its failure to penetrate effectively elsewhere. An omission may be noted among the drawbacks given of this method, viz., a definitely high rate of iris prolapse, regarded by some as perhaps the chief objection to this operation, since excision of the prolapse may entail impaction or loss of vitreous.

Smith's very valuable method of lid control is evidently practised a good deal in Madras. Possibly the very free instillation of cocain with adrenalin now utilized by some surgeons in India, may largely remove the need for special lid control.

No mention is made of moistening the cornea during operation. In the very hot northern plains of India patients and surgeon alike are often averse to cataract extraction in the hot weather. After some experience of Sind the reviewer believes that with the help of a fan in a closed room, any such restriction is unnecessary, except when a dust storm is actually blowing. But sterile water should be dropped on the cornea, as may be necessary, especially if free cocain instillation is practised. The keratitis mentioned on page 282 of the book may be the result of drying of the cornea during operation.

In the section on the conjunctiva, cornea, lids, etc., the reviewer is glad to meet some old acquaintances. It has always seemed inexplicable that earlier workers in India should have left absolutely no record of observations such as are here collected. Fig. 81 shows the moderate pigmentation characteristic of bulbar spring catarrh in dark- and yellow-skinned races.

The lid thickenings mentioned on page 346 have proved to be due essentially to colloid (hyalin) degeneration of the tissues, sometimes with further secondary changes, e.g., in one recorded case, true bone formation.

The final section on eye affections in general diseases contains much of interest, such as the recent observations on dysenteric conjunctivitis and iritis. The vexed question of malarial eye affections is treated fairly and impartially.

The book is fully illustrated from photographs, excellently reproduced. It is everywhere concise, but thorough, and apparently with no serious omissions. As is to be expected of Col. Elliot, the descriptions are refreshingly apt, clear, and forcible. Doubtless 
it will long remain the standard work on the subject, with every probability of new editions being called for. It cannot fail to add to the author's high reputation.

H. HERBERT.

Diseases of the Eye. By M: Stephen Mayou. Third edition. London: Henry Frowde, Oxford University Press; Hodder and Stoughton, Ltd., Warwick Square, E.C. 4. P.p. 326, with 124 original illustrations and eight colour plates. Price 10s. 6d. net.

This text-book is one of the valuable series of the Oxford Medical Manuals. The author in his preface to the third edition states that in consideration of the fact that the medical student's curriculum is already overburdened, he has only added such new material as was necessary to bring the volume up to date. As is only right in such a text-book the author is somewhat dogmatic, but always lucid and easy to follow. The illustrations, especially the pathological ones, are of considerable value and should prove of much assistance to the student in following the text descriptions. We would particularly commend the account of the hook operation for iridotomy, which was described in the. March number of this journal. On page 245 the author advises that a little protargol should be left in the lacrimal sac after irrigation. We do not think this is safe advice to give as we have ourselves come across three cases in which this procedure was followed by severe silver staining.

The volume is of a handy size for the pocket and should prove one of the most useful of students' handbooks.

E. E. H.

\section{NOTES}

Deaths

WE regret to announce that W. P. Nuêl died at Liège on August 21, 1920. Born at Tétange, in the Grand Duchy of Luxembourg, in 1847, he pursued his professional studies in the University of Gand, of which he became a doctor of medicine in 1870 . He then worked with Panas, Galezowski, Snellen, and Saemisch. His next step was to go into general practice at Eich, a small village near Luxembourg. The scientific work accomplished in that remote village attracted general attention, and in 1877 Nuël was called to the chair of ophthalmology in Louvaine. A few years later (1880) he was appointed professor of physiology in the University of Gand. From 1885 to 1919 he was professor of ophthalmology and of the 